\title{
A REVIEW ON BUILDINGS ENERGY CONSUMPTION INFORMATION
}

\author{
Luis Pérez-Lombard* - 1pl@us.es \\ José Ortiz** - ortizj@bre.co.uk \\ Christine Pout**-poutc@bre.co.uk \\ (*) Grupo de Termotecnia. Escuela Superior de Ingenieros. Universidad de Sevilla. \\ (**) BRE (Building Research Establishment)
}

\begin{abstract}
The rapidly growing world energy use has already raised concerns over supply difficulties, exhaustion of energy resources and heavy environmental impacts (ozone layer depletion, global warming, climate change, etc.). The global contribution from buildings towards energy consumption, both residential and commercial, has steadily increased reaching figures between 20 and $40 \%$ in developed countries, and has exceeded the other major sectors: industrial and transportation. Growth in population, increasing demand for building services and comfort levels, together with the rise in time spent inside buildings, assure the upward trend in energy demand will continue in the future. For this reason, energy efficiency in buildings is today a prime objective for energy policy at regional, national and international levels. Among building services, the growth in HVAC systems energy use is particularly significant (50\% of building consumption and $20 \%$ of total consumption in the USA). This paper analyses available information concerning energy consumption in buildings, and particularly related to HVAC systems. Many questions arise: Is the necessary information available? Which are the main building types? What end-uses should be considered in the breakdown?
\end{abstract}


Comparisons between different countries are presented specially for commercial buildings. The case of offices is analysed in deeper detail.

\section{Keywords}

Building energy use, HVAC consumption, Air conditioning consumption.

\section{World energy use}

The rapidly growing world energy use has already raised concerns over supply difficulties, exhaustion of energy resources and heavy environmental impacts (ozone layer depletion, global warming, climate change, etc). The International Energy Agency has gathered frightening data on energy consumption trends. During the last two decades (1984-2004) primary energy has grown by $49 \%$ and $\mathrm{CO}_{2}$ emissions by $43 \%$, with an average annual increase of $2 \%$ and $1.8 \%$ respectively (Figure 1 ).

Current predictions show that this growing trend will continue. Energy use by nations with emerging economies (Southeast Asia, Middle East, South America and Africa) will grow at an average annual rate of $3.2 \%$ and will exceed by 2020 that for the developed countries (North America, Western Europe, Japan, Australia and New Zealand) at an average growing rate of $1.1 \%$ (Figure 2). The case of China is striking, taking only 20 years to double its energy consumption at an average growing rate of $3.7 \%$.

Interesting consequences can be obtained from the analysis of the trend of main world energy indicators [1] between 1973 and 2004 (Table 1): (1) the rate of population growth is well below the GDP, resulting in a considerable rise of per capita personal income and global wealth, (2) primary energy consumption is growing at a higher rate 
than population, leading to the increase of its per capita value on $15.7 \%$ over the last 30 years, (3) $\mathrm{CO}_{2}$ emissions have grown at a lower rate than energy consumption showing a 5\% increase during this period, (4) electrical energy consumption has drastically risen (over two and a half times) leading to a percentage increase in final energy consumption (18\% in 2004), (5) efficiency in exploiting energy resources, shown as the relation between final and primary energy, has declined by 7 percentage points, especially due to soaring electrical consumption, and (6) final and primary energy intensities have dropped because of the higher rate of growth of the GDP over the energy consumption increasing ratio, resulting in an overall improvement of the global energy efficiency.

These figures confirm the relationship linking energy consumption with economic development and population growth, and question global policy attempts to invert this trend by increasing energy efficiency (including renewable and green technologies). Globalisation, improvement of living conditions in emerging regions and the development of communication networks, promote developed nations' life style and raise energy needs to consumption patterns that, without doubt, will exhaust fossil fuels and will produce a serious environmental impact. In this sense, current energy and socio-economic systems are definitively unsustainable.

\section{Energy consumption in buildings}

Final energy consumption is usually shown split into three main sectors: industry, transport and 'other', including in the last-named, agriculture, service sector and residential. This makes it considerably difficult to gather information about building energy consumption. For example, energy consumption in buildings other than 
dwellings constitutes a fraction of the services shared within the 'other' key sector. Considering its overall significance in developed countries (buildings account for a 20 to $40 \%$ of the total final energy consumption), we believe it should be accounted for independently and become the third main sector, broken down, at least, for domestic and non-domestic buildings.

Growth in population, enhancement of building services and comfort levels, together with the rise in time spent inside buildings, have raised building energy consumption to the levels of transport and industry (Table 2). Especially significant is the reduction of the ratio of industry (9 points) and the expansion of 'other' ( 6 points) due to buildings.

The term "other sectors" is ambiguous and produces great confusion. Many international, national and regional sources, include different end uses within this concept, which makes any sort of comparison difficult. Looking to the evolution (Figure 3) and importance (Table 3) of building energy consumption, we conclude:

(1) In the UK building energy consumption has increased at a rate of $0.5 \%$ per annum, which is slightly below the European figure of $1.5 \%$. In contrast building energy consumption in Spain is increasing at a rate of $4.2 \%$ per annum, well above both the European and the North American (1.9\%) rate. Reasons can be found in the economic growth, expansion of the building sector and the spread of building services, especially Heating, Ventilation and Air-Conditioning (HVAC) systems. 
(2) In 2004, building consumption in the EU was $37 \%$ of final energy, bigger than industry (28\%) and transport (32\%). In the UK, the proportion of energy use in building $(39 \%)$ is slightly above the European figure. This is in part due to the shift away from heavy industry towards service sector activities. In contrast the figure for Spanish buildings is only $23 \%, 14$ points below Europe, and expected to rise strongly as economic growth lead to convergence with the European average.

The service sector, which covers all commercial and public buildings, includes many types of buildings (schools, restaurants, hotels, hospitals, museums...) with a wide variety of uses and energy services (HVAC, domestic hot water (DHW), lighting, refrigeration, food preparation, etc.). Growth both economical and in population, increases the demand of services (health, education, culture, leisure, etc) and the energy consumption. In USA, energy consumption in the service sector has expanded from 11 to $18 \%$ from the 1950 s. In the UK, service energy use in 2004 accounted for around $12 \%$ of all final energy use, similar to the EU average (11\%). By contrast the Spanish figure was only $8 \%$ but it is reporting massive increases and has been multiplied by 2.5 between 1980 and 2000.

In the residential sector, size and location are key factors for energy consumption. Small flats need less energy as there is less conditioned and transfer area, and also less occupation. The amount and type of energy used in dwellings are mainly related to weather, architectural design, energy systems and economic level of the occupants. By and large, dwellings in developed countries use more energy than those in emerging economies and it is expected to continue growing due to the installation of new 
appliances (air conditioners, computers, etc). In USA, dwellings consume $22 \%$ of the total final energy use, compared with $26 \%$ in the EU. The UK figure is $29 \%$, well above the Spanish $15 \%$ mainly due to a more severe climate and building type (predominance of independent houses over blocks).

The EIA, in its International Energy Outlook [2], analyses and forecasts future trends in building energy consumption (Figure 4). Energy use in the built environment will grow by $34 \%$ in the next 20 years, at an average rate of $1.5 \%$. In 2030 , consumption attributed to dwellings and the non-domestic sectors will be $67 \%$ and $33 \%$ respectively (approximately). Spread in Southeast Asian, and therefore, the growth of construction will boost energy demand on the residential sector. Forecasts predict that both developed and non-developed economies will be balanced in the use of energy in dwellings by 2010. Economic, trading and population growth in emerging economies will intensify needs for education, health and other services, together with the consequential energy consumption. It is expected that energy consumption in the service sector in non-developed countries will be doubled in the next 25 years, with an annual average growth rate of $2.8 \%$.

\section{Heating, ventilation and air conditioning (HVAC)}

The proliferation of energy consumption and $\mathrm{CO}_{2}$ emissions in the built environment has made energy efficiency and savings strategies a priority objective for energy policies in most countries. A clear example is the European Energy Performance of Buildings Directive (EPBD) [3]. Especially important has been the intensification of energy consumption in HVAC systems, which has now become almost essential in 
parallel to the spread in the demand for thermal comfort, considered a luxury not long ago. It is the largest energy end use both in the residential and non-residential sector, comprising heating, ventilation and air conditioning.

Its predominance is obvious when it is compared with other end uses. For dwellings (Table 4) it represents about half the energy consumption more than doubling that for DHW. For non domestic buildings, IDAE [4] estimates HVAC energy consumption to be around $48 \%$, still lower than the $57 \%$ in the USA, and similar to figures from other sources [5]. At the European level, the weight of HVAC is unknown; however, many sources show a significant increase in the use of air conditioning, especially in Southern countries (Spain and Italy accounts for more than 50\% of the European market), creating serious supply difficulties during peak load periods.

In Europe, data produced by the administration at national, regional or local levels is insufficient to efficiently plan future energy policies for buildings and to coordinate measures to address each of the end uses. Analysis by sectors, as those produced by the EIA for residential [6] and commercial buildings [7] should be funded by governments, so that a comprehensive database of the building stock (type, area, location, age...) and energy parameters (consumption, expenditures, fuels, end uses...) can be the basis for future planning.

By and large, HVAC consumption in developed countries accounts for half the energy use in buildings and one fifth of the total national energy use. Moreover, predictions indicate a massive growth in energy consumption and conditioned area in the EU [9] during the next 15 years, increasing approximately in 50\%. 


\section{Non-domestic buildings}

In non-domestic buildings, the type of use and activities make a huge impact on the quality and quantity of energy services needed. However, few sources offer data by typology and there is not consensus on a universal classification, which makes the analysis extremely difficult. After revising several sources, some general conclusions may be reached:

(1) In the UK energy consumption in this sector has stabilised somewhat in recent years, with increases in floor area and increased servicing levels being offset by increases in efficiency. Across the rest of Europe energy consumption in the commercial sector grows at a higher rate than other sectors due predominantly to the expansion of HVAC systems in new buildings [10]. In the UK new build rates in the service sector are typically around $2 \%$, whilst in Spain the average annual rate of growth from 2000 is $6.1 \%$, and forecasts show that this will continue increasing. In 2003, this sector was accounting for $12 \%$ of the total energy consumption compared to USA (18\%) and equal to EU (11\%). Energy policies have focused on the residential and industrial sectors and have tended to overlook the service sector, despite its highest growing rate.

(2) Office and retail are the most energy intensive typologies typically accounting for over $50 \%$ of the total energy consumption for non-domestic buildings. Hotels and restaurants, hospitals and schools follow. (Table 5)

(3) HVAC is the main end use with a weight close to $50 \%$, lighting follows with $15 \%$ and appliances with $10 \%$. Building type is critical in how energy end uses are 
distributed (Figure 5) and in their energy intensity (Table 6). This makes it essential to develop independent studies by building types.

\section{Office Buildings}

Within the commercial sector, office buildings are, together with retail, those with the biggest consumption and $\mathrm{CO}_{2}$ emissions. In USA offices account for $17 \%$ of total non domestic area and about $18 \%$ of the energy use, equivalent to a $3.2 \%$ of the total consumption. In Spain, they account for a third of the commercial sector energy consumption and almost $2.7 \%$ of total energy consumed and in the UK for $17 \%$ of energy consumption and $2 \%$ of total energy use. Therefore, it is advisable to start the commercial analysis with office buildings. Other reasons, supporting energy surveys for this typology are:

(1) The substantial increase of total built area of office buildings due to the economical prosperity with many new business developments in mayor city outskirts [11]. During 1990-2000, 9.3 $\mathrm{Mm}^{2}$ were built in Spain, with no reliable information on the total built area. In USA, per capita area is about $4 \mathrm{~m}^{2}$, well above the European figure of $2 \mathrm{~m}^{2} /$ per. In the UK the total floor area of offices has increased by around 4\% between 2000 and $2005[13]$.

(2) The amount of artificial lighting required, IT equipment use and air conditioned area have steadily increased. In Spain, more than $90 \%$ of companies use IT equipment and virtually all new offices are conditioned. Even in mild weather as in the UK more than half of new offices are conditioned. 
(3) It is a typology quite uniform across the building stock, both in envelope and building services, with three key energy end uses, HVAC, lighting and appliances, adding up together to about $85 \%$ of the total. (Table 7 )

\section{Conclusions}

Energy consumption of buildings in developed countries comprises 20 to $40 \%$ of total energy use and is above industry and transport figures in EU and USA. However, available information is clearly insufficient and not proportional to its importance. It is not considered as an independent sector and there is a lack of consistent data which makes it difficult to understand the underlying changes that affect energy consumption in this sector. It is essential to make available comprehensive building energy information to allow suitable analysis and efficiently plan energy policies for the future. In that respect, studies developed by the EIA on the energy consumption of residential and commercial buildings in the USA are a valuable reference.

Proliferation of energy consumption and $\mathrm{CO}_{2}$ emissions on the built environment have made energy efficiency strategies a priority for energy policies developing new building regulations and certification schemes which now include minimum requirements. With the consolidation of the demand for thermal comfort, HVAC systems (and its associated energy consumption) have become an unavoidable asset, accounting for almost half the energy consumed in buildings, and around 10 to $20 \%$ of total energy consumption in developed countries. 
The growing trend in building energy consumption will continue during the coming years due to the expansion of built area and associated energy needs, as long as resource and environmental exhaustion or economic recession allows it. Private initiative together with government intervention through the promotion of energy efficiency, new technologies for energy production, limiting energy consumption and raising social awareness on the rational use of energy will be essential to make possible a sustainable energy future. 


\section{References}

[1] International Energy Agency. Key World Energy Statistics, 2006.

[2] Energy Information Administration. International Energy Outlook 2006. U.S. Department of Energy, June 2006.

[3] Directive 2002/91/CE of the European Parliament and of the Council of 16 December 2002 on the energy performance of buildings, 2002.

[4] Ministerio de Economía. Estrategia de ahorro y eficiencia energética en España 2004-2012. Noviembre 2003.

[5] Pérez-Lombard, L., Adnot, J., Ortiz, J. A. and Rivière, P. HVAC systems energy comparisons for an office building. Proceedings of Climamed. Lisbon, 2004.

[6] Energy Information Administration. Residential Energy Consumption Survey (RECS). U.S. Department of Energy, 2001.

[7] Energy Information Administration. Commercial Buildings Energy Consumption Survey (CBECS). U.S. Department of Energy, 2003.

[8] Instituto para la diversificación y Ahorro de la energía (IDAE). Eficiencia Energética y Energías Renovables ( $\mathrm{N}^{\mathrm{o}}$ 8). Madrid, octubre de 2006.

[9] EECCAC (Energy Efficiency and Certification of Central Air Conditioners) project for the Directorate General Transportation-Energy of the Commission of the European Union. Final report. April 2003.

[10] Ministerio de Industria, Turismo y Comercio. La Energía en España 2005. Madrid 2006.

[11] ACE (The Association for the Conservation of Energy). Energy efficiency in offices: Assessing the situation. March 2003. 
[12] Best Practice Programme energy Consumption Guide 19, Energy use in offices. Carbon Trust, December 2000.

[13] Commercial and Industrial Floorspace and Rateable Value Statistics 2005 (2005 Revaluation, Office of the Deputy Prime Minister, London, February 2006. 
Figure 1. Primary energy consumption, $\mathrm{CO}_{2}$ emissions and world population.

Reference year 1984. Source: International Energy Agency (IEA).

Figure 2. World energy use by region. Source: Energy Information Administration (EIA).

Figure 3. Energy consumption of buildings. Reference year 1994. Source: Eurostat and EIA.

Figure 4. Buildings energy consumption outlook. Source: EIA.

Figure 5. Consumption by end use for different building types. Source: EIA 
Table 1. Global energy indexes evolution between 1973 and 2004. Source: International Energy Agency (IEA).

\begin{tabular}{l|ccc}
\hline \multicolumn{1}{c|}{ Parameter } & 1973 & 2004 & Ratio (\%) \\
\hline Population (Millions) & 3938 & 6352 & 61.3 \\
GDP (G\$ year 2000) & 14451 & 35025 & 142.4 \\
Per capita income (\$ year 2000) & 3670 & 5514 & 50.2 \\
Primary energy (Mtoe) & 6034 & 11059 & 83.3 \\
Final energy (Mtoe) & 4606 & 7644 & 66.0 \\
Final energy / Primary energy & 0.76 & 0.69 & -9.4 \\
Electrical energy (Mtoe) & 525 & 1374 & 161.8 \\
Electrical energy / Final energy & 0.11 & 0.18 & 63.5 \\
Per capita primary energy (toe) & 1.53 & 1.77 & 15.7 \\
Per capita CO 2 emissions (ton) & 3.98 & 4.18 & 5.0 \\
Primary energy intensity (toe/ G\$ year 2000) & 418 & 316 & -24.4 \\
Final energy intensity (toe/ G\$ year 2000) & 319 & 218 & -31.5 \\
\hline
\end{tabular}


Table 2. World final energy consumption by sector. Source: IEA.

\begin{tabular}{c|ccc}
\hline $\begin{array}{c}\text { Final Energy Consumption } \\
\text { by sector (\%) }\end{array}$ & 1973 & 2004 & Ratio \\
\hline Industry & 39 & 30 & 0.76 \\
Transport & 25 & 28 & 1.14 \\
Other sectors & 36 & 42 & 1.16 \\
\hline
\end{tabular}


Table 3. Weight of buildings energy consumption. Year 2004. Sources: EIA, EuroStat, and BRE.

\begin{tabular}{c|ccc}
\hline $\begin{array}{c}\text { Final Energy Consumption } \\
(\%)\end{array}$ & Commercial & Residential & Total \\
\hline USA & 18 & 22 & 40 \\
UK & 11 & 28 & 39 \\
EU & 11 & 26 & 37 \\
Spain & 8 & 15 & 23 \\
World & 7 & 16 & 24 \\
\hline
\end{tabular}


Table 4. Energy consumption by end uses in the residential sector. Year 2003. Source: EIA and IDAE [8] and BRE.

\begin{tabular}{lcccc}
\hline End uses in the Residential sector (\%) & Spain & UE & USA & UK \\
\hline Space conditioning & 42 & 68 & 53 & 62 \\
Domestic Hot Water (DHW) & 26 & 14 & 17 & 22 \\
Lighting and appliances & 32 & 18 & 30 & 16 \\
\hline
\end{tabular}


Table 5. Energy use in the commercial sector by building type. Year 2003. Sources: EIA, IDAE and BRE.

\begin{tabular}{lccc}
\hline \multicolumn{1}{c}{ Building type } & USA (\%) & Spain (\%) & UK (\%) \\
\hline Retail & 32 & 22 & 22 \\
Offices & 18 & 33 & 17 \\
Hotels \& restaurants & 14 & 30 & 16 \\
Schools & 13 & 4 & 10 \\
Hospitals & 9 & 11 & 6 \\
Leisure & 6 & - & 6 \\
Others & 9 & - & 23 \\
\hline
\end{tabular}


Table 6. Average energy use intensity by building type in USA. Year 2003. Source: EIA.

\begin{tabular}{lcc}
\hline \multicolumn{1}{c}{ Building type } & $\mathrm{kWh} / \mathrm{m}^{2}$ year & Ratio \\
\hline Dwellings & 147 & 1 \\
Retail & 233 & 1.6 \\
Schools & 262 & 1.8 \\
Offices & 293 & 2 \\
Hotels & 316 & 2.1 \\
Supermarkets & 631 & 4.3 \\
Hospitals & 786 & 5.3 \\
Restaurants & 814 & 5.5 \\
\hline
\end{tabular}


Table 7. Energy consumption in offices by end use. Sources: EIA, BRE [12] and IDAE.

\begin{tabular}{lccc}
\hline \multicolumn{1}{c}{ Energy End Uses } & USA (\%) & UK (\%) & Spain (\%) \\
\hline HVAC & 48 & 55 & 52 \\
Lighting & 22 & 17 & 33 \\
Equipment (appliances) & 13 & 5 & 10 \\
DHW & 4 & 10 & - \\
Food preparation & 1 & 5 & - \\
Refrigeration & 3 & 5 & - \\
Others & 10 & 4 & 5 \\
\hline
\end{tabular}

